\title{
Interdyscyplinarność jako jeden ze współczesnych wymogów bycia naukowcem - wyzwania i dylematy
}

DOI: http://dx.doi.org/10.12775/ZN.2019.013

Celem mojego wystąpienia jest podzielenie się z Państwem przemyśleniami i skłonienie do refleksji nad interdyscyplinarnością w kontekście bycia naukowcem. Interdyscyplinarność pojawia się głównie w dyskusjach nad polityką naukową i sposobami prowadzenia badań. Naukowcom zarzuca się zamykanie się w wąskich specjalizacjach, brak umiejętności pracy w zespołach badawczych i brak interdyscyplinarnego podejścia do rozwiązywania problemów złożonych, a często zapętlonych. Podkreśla się potrzebę zintegrowanej współpracy między dyscyplinami. Badania interdyscyplinarne integrują dane, informacje, techniki, narzędzia, perspektywy, pojęcia, teorie dwóch lub więcej dyscyplin we wspólnej pracy nad problemem, który przekracza granice dyscyplin.

Moja pierwsza wątpliwość jest następująca: czy postulat interdyscyplinarności jest (1) wyrazem przekonania - że wnosi ona do nauki, do poznania ważną wartość - wyrażającego się poprzez wspieranie takiego sposobu uprawiana nauki, czy (2) rodzajem nowomowy autorów polityk naukowych?

Drugą interesującą mnie kwestią jest szukanie odpowiedzi na następujące pytania:

- Jak postulat interdyscyplinarności oddziałuje na sposób uprawiania naukiw codziennym życiu naukowca?

- Z jakimi formami aktywności naukowej koreluje interdyscyplinarność i jakie kryją się w nich zagrożenia?

Lektura ustaw z 2003, 2005 i 2018 r. oraz towarzyszących im rozporządzeń pokazuje, że ustawodawca w odniesieniu do sposobu uprawiania nauki nie formułuje wprost oczekiwań związanych z interdyscyplinarnością. Można pomyśleć, że traktuje ją bardziej jako formę pracy, a zatem domenę autonomii akademickiej. 
I choć interdyscyplinarność zauważano jeszcze na początku XXI w., to w nowej ustawie nie ma tego terminu.

1. W ustawie o stopniach naukowych i tytule naukowym oraz o stopniach i tytule w zakresie sztuki z 2003 r. (po nowelizacjach, stan na 15 września 2017 r.) dopuszczano interdyscyplinarne rozprawy doktorskie.

2. W ustawie o szkolnictwie wyższym z lipca 2005 r. pojawił się zapis o interdyscyplinarnych kierunkach studiów.

3. W ustawie wprowadzającej Prawo o szkolnictwie wyższym, z 3 lipca 2018 r., termin ,studia interdyscyplinarne” został zastąpiony terminem „studia wspólne”.

4. W najnowszej ustawie 2.0 z 20 lipca 2018 r. nie ma terminu ,,interdyscyplinarny" (w żadnej formie):

- Określając cechy pożądanych osiągnięć, ustawodawca pisze, że dorobek naukowy ma być znaczący w danej dziedzinie lub dyscyplinie, aktualny w zakresie danego zadania.

- Zespoły są najczęściej opisywane jako zespoły ekspertów dla danej dyscypliny lub grupy dyscyplin.

- Jeżeli badacz ma osiągnięcia w więcej niż jednej dyscyplinie, to może zostać mu nadany stopień doktora lub doktora habilitowanego $\mathrm{w}$ jednej $\mathrm{z}$ nich.

- W przypadku publikacji wieloautorskich senat ustala zasady weryfikacji (dyscypliny, której one dotyczą).

- Recenzentem doktoratu może być osoba prowadząca samodzielną działalność naukową w dyscyplinie, w której jest przygotowywana rozprawa doktorska.

- Od kandydata do tytułu oczekuje się doświadczenia pod względem uczestnictwa w zespołach badawczych finansowanych w drodze konkursów (nie ma mowy o ich interdyscyplinarności).

Podsumowując tę część: po dokonanym przeglądzie zapisów ustawowych sklaniałabym się raczej do uznania, że postulat interdyscyplinarności jest rodzajem nowomowy autorów ustawy, gdyż nie lączy się z jej wspieraniem.

Co ten stan prawny oznacza dla konkretnego naukowca?

1. Musi on skoncentrować zainteresowania na jednej dyscyplinie. W przypadku doktoratu ustawa o stopniach naukowych i tytule naukowym mówiła o konieczności wskazania dyscypliny wiodącej.

2. Recenzentami muszą być osoby posiadające stopień doktora habilitowanego lub tytuł $\mathrm{w}$ dyscyplinie, w której jest przygotowywana rozprawa czyli nie ma szans na rzetelną ocenę dorobku interdyscyplinarnego.

3. Centralna Komisja do spraw Stopni i Tytułów Naukowych przez wiele lat bardzo dyscyplinowała rady jednostek (łącznie z ograniczaniem ich uprawnień), które powoływały recenzentów z pokrewnych dyscyplin, ale 
z innych dziedzin, i skutecznie wyeliminowała takie praktyki - niejednokrotnie ze szkodą dla nauki. Było to zabójcze dla rozwoju dyscyplin niszowych, a także wyłaniających się na styku dyscyplin, a czasem dziedzin wiedzy.

4. W efekcie ścieżki kariery, ewaluacja, rankingi opierają się na dyscyplinach, a większość nauczycieli akademickich postrzega interdyscyplinarność jako dyletanctwo, powierzchowne podejście do nauki.

5. W skali międzynarodowej wąskodyscyplinowe podejście do nauki stało się także przedmiotem krytyki. Podczas „Forum Globalnej Nauki OECD”, zorganizowanego w Paryżu, w październiku 2016 r., wybrzmiała bardzo silna krytyka peer review, m.in. z powodu złego systemu doboru recenzentów w odniesieniu do dorobku niszowego w wyłaniających się obszarach i dyscyplinach badawczych oraz ocen nieadekwatnych do rzeczywistych walorów osiągnięć. Uważano, że szanse ma tylko dorobek mainstreemowy. Natomiast nowe, oryginalne, innowacyjne pomysły - na styku różnych dyscyplin - przepadają $\mathrm{w}$ procesie oceny.

\section{Drugi aspekt interdyscyplinarności dotyczy praktyki działania naukowego.} Wszyscy wiemy, jak pożądane jest obecnie zaangażowanie naukowców w prace międzynarodowych, interdyscyplinarnych zespołów badawczych. Decydenci nie ustają w krytykowaniu polskich naukowców za słabe uczestnictwo w programie Horyzont czy innych międzynarodowych programach badawczych. Nawiązał do tego publicznie - na konferencji KRASP poświęconej 30-leciu transformacji polskiego szkolnictwa akademickiego, zorganizowanej pod koniec 2019 r., 100 lat po przyjęciu pierwszej polskiej ustawy o szkolnictwie wyższym - niedawny wiceminister Piotr Müller, mówiąc o mankamentach najnowszej regulacji. Za najważniejszy z nich uznał brak możliwości nagradzania zespołów interdyscyplinarnych.

$\mathrm{Na}$ marginesie warto powiedzieć, że interdyscyplinarność silnie wiąże się z pracą w zespołach projektowych. Nikt nie mówi jednak o tym, że w zespołach interdyscyplinarnych, częściej niż w innych zespołach badawczych, naukowcy są zatrudniani do realizacji i na czas realizacji określonych projektów. Ich egzystencja jest często związana z umowami projektowymi. Są to tzw. prekariusze uprawiający naukę w sytuacji niepewności, nietrwałości zatrudnienia. Gdy wskaźnik sukcesu w konkursach na finansowanie projektów spada w niektórych programach poniżej 10\% (tak wygląda rzeczywistość w Wielkiej Brytanii, Niemczech czy Holandii), to zaczynamy lepiej rozumieć status coraz liczniejszej grupy młodych naukowców. Możemy sobie też uświadomić, jak zmieniają się warunki uprawiania nauki. One nie pozostają bez wpływu na relacje pomiędzy konkurującymi ze sobą naukowcami oraz jednostkami badawczymi.

Jak wygląda świat codziennego życia naukowca prekariusza? Przed jakimi staje on dylematami? Co jest dla niego najważniejsze: 
- rozwój nauki czy budowanie swojego CV? (patrz: kryteria oceny wniosków np. w konkursie OPUS)

- rozwój nauki czy budowanie sieci kontaktów projektowych?

- etos akademicki czy sprawność projektowa?

Do tego dochodzi jeszcze brak stabilności wymagań, co uniemożliwia strategiczne podejście do planowania przedsięwzięć badawczych. W ostatnich dniach NCN zdecydował o włączeniu programu HARMONIA - dotyczącego projektów międzynarodowych - do konkursu OPUS. Spodziewano się, że projekty bazujące na mocnych zespołach międzynarodowych zostaną w nim docenione. Dokładne wytyczne ukazały się na początku listopada; okazało się, że na kryteria oceny składają się: ocena kierownika $-40 \%$, ocena merytoryczna $-55 \%$, inne elementy, w tym wymiar międzynarodowy $-5 \%$. W opisie projektu tylko kierownik nie jest bezimienny (reszta zespołu jest anonimowa - nawet nie ma możliwości pokazać jego potencjału).

Na przykładzie interdyscyplinarności widać, że politycy, osoby zarządzające nauką mają pewne wyobrażenia o sposobie uprawiania nauki, od której oczekują rozwiązywania złożonych problemów. Stawiają wymagania, uzależniając od osiąganych wyników byt jednostek i zespołów badawczych. Jednocześnie nie uruchamiają adekwatnych instrumentów wsparcia dla promowanych sposobów uprawiania nauki, a interdyscyplinarność jest tego najlepszym dowodem. 